\title{
Anadara granosa substitution in feed to improve the zinc, protein of the feed, serum albumin, and body weight of malnourished rats
}

\author{
${ }^{1,}{ }^{*}$ Solang, M. and ${ }^{2}$ Adriani, $\mathrm{M}$. \\ ${ }^{1}$ State University of Gorontalo, Faculty of Mathematics and Natural Sciences, Department of Biology, Jl. \\ Jendral Sudirman No. 6 Kota Gorontalo, 96128, Gorontalo, Indonesia \\ ${ }^{2}$ Airlangga University, Faculty of Public Health, Health Science Department, Campus C, Mulyorejo, Kec. \\ Mulyorejo, Surabaya, 6011, Jawa Timur, Indonesia
}

\begin{abstract}
Article history:
Received: 21 August 2020

Received in revised form: 7 September 2020

Accepted: 21 November 2020

Available Online: 5

December 2020
\end{abstract}

Keywords:

Anadara granosa,

Feed,

Protein,

Growth,

Malnourished

DOI:

https://doi.org/10.26656/fr.2017.5(1).458

\begin{abstract}
The objective of this paper was to evaluate zinc and protein feed levels of Anadara granosa flour substitution and its effect of feed on serum albumin and body weight of a malnourished rat (Rattus norvegicus). This study comprised two stages: 1) analysis of protein and zinc level of the feed, and 2) feed test on rat using separate sample pre-test and post-test control group design. The malnourished rat was treated with dried rice; the dried rice was substituted with $12.5 \%, 25 \%$, and $50 \%$ of Anadara granosa flour. Further, at room temperature, the flour can be kept for six months. This study revealed that the Anadara granosa-substituted feed had zinc levels between $0.999 \mathrm{ppm}-2.296 \mathrm{ppm}$ and protein levels of $14.81 \%-26.39 \%$. On the other hand, the non-substituted feed had 0.791 ppm of zinc, and the protein level was $8.46 \%$. Provision of the feed substituted with Anadara granosa flour increased the albumin serum level $(\mathrm{p}=0.000)$ and the bodyweight of malnourished rats significantly $(\mathrm{p}=0.002)$. This study revealed that substitution of Anadara granosa flour in feed could improve the zinc and protein level of the feed, which in turn improved the growth of malnourished rats (as the albumin level and the bodyweight also improved).
\end{abstract}

\section{Introduction}

Malnutrition, especially zinc deficit, is largely found on children in developing countries; in childhood stage, children need a higher zinc intake (Yanagisawa, 2004; Parveen and Dipti, 2016). Zinc deficit would influence homeostasis within the biological system (Kaur et al., 2016). A nutrition deficit condition that occurs for a long time might lead to stunting (Chirande et al., 2015; Mardewi et al., 2016). Stunting is one of the prominent health problems in Indonesia as its prevalence is still currently above $20 \%$ (Kemenkes, 2018). Provision of zinc supplements is proven to be able to treat stunting (Kusudaryati et al., 2017) since children with stunting have a low level of zinc and albumin serum levels. Thus, the administration of Vitamin A with zinc supplements could reduce infection risk and improve the linear growth of children with stunting (Adriani and Wirjatmadi, 2014).

Gibson and Ferguson (1994) reported that zinc deficiency could be solved by increasing zinc intake. As what has been done in Africa, increasing zinc intake through zinc-rich meats and meals that are economically and culturally acceptable in that area, the deficiency problem could be addressed. Zinc is commonly available in high protein food. Animal-based meals are the main source of zinc in the human diet (Agustian et al., 2009; Kaur et al., 2016). Zinc is one of the most essential elements in nutrition for humans and animals. In the growth process, zinc helps in protein synthesis to form new cells, growth, and bone development (Agustian et al., 2009). Zinc also has several physiological characteristics and activates enzymes within the body (Kaur et al., 2016).

Anadara granosa is one of the seafood that is rich in zinc contents. Fresh Anadara granosa contain 19.48\% of protein and $13.91 \mathrm{ppm}$ of zinc (Nurjanah et al., 2005). It also contains complex amino acids. The protein contents in the Anadara granosa would help absorb zinc and increase protein intake to the body. Therefore, zinc and protein in the Anadara granosa will work in synergy to improve zinc levels of malnutrition rats (Solang et al., 2013). On top of that, zinc also plays a role in inducing metallothionein (zinc-binding protein); thus, it regulates 
the amino acid as the precursor for the synthesis of albumin (Tekeli, 2002). The level of albumin plasma could be used as a sensitive indicator of nutrition status that reflects a diet pattern (Kuwahata et al., 2017). The previous studies above serves as the rationale, as the present study aims to evaluate zinc and protein in Anadara granosa flour-substituted feed and the feed's effect on serum albumin levels and body weight of a malnourished rat (Rattus norvegicus). This study hypothesized that Anadara granosa-substituted feeds can improve zinc and protein feed levels, and the consumption of the feeds can improve albumin levels and body weight of malnourished rat.

\section{Material and methods}

\subsection{Research design and sample}

The Anadara granosa used as substitute feeds in this study were taken from Gorontalo province, Indonesia. Rats were fed in the form of pellets consisting of standard feed, dried rice, and Anadara granosa flour substitution. The standard pellet feed produced by PT Charoen Pokpan contain 13\% water, $13-15 \%$ protein, $3 \%$ fat, $6 \%$ ash, and $0.8 \%$ calcium. The dried rice feed was used to create malnutrition conditions. The dried rice was made of leftover rice. The rice that will no longer be consumed was set out to dry under the sun. After adding flour, the rice is cooked and stirred until mixed well. The dough is poured into a grinder and was shaped into a pellet. Further, the pellet was set to dry under the sun for the second time.

Further, the processes of making the flour are as follows. First, the whole cockles were boiled until they open. Then, the soft tissues of the cockles were removed. After that, the tissues were cut into small pieces. All the cut tissues were dried in the sun to get a constant dry weight. The tissues, after the sun-drying process, were finely milled and sifted to get the cockle flour. Anadara granosa flour contained $27.26 \%$ of protein and 0.7913 ppm of zinc and the flour can be kept at room temperature for six months.

This study was designed on testing rats using the Separate Sample Pre-Post Test Control Group Design (Campbell and Stanley, 1963; Handley et al., 2018). On the first test, 12 male Wistar rats aged 6 weeks with 115-120 g bodyweight were given standard feed (normal group). Meanwhile, 36 male Wistar rats aged 6 weeks with a bodyweight of $110-120 \mathrm{~g}$ were treated using dried rice pellet feed with $8 \%$ of protein (nutrition deficit group). In the $8^{\text {th }}$ weeks, 4 rats from the normal control group and 4 rats from the nutrition deficit group were slaughtered to test their albumin level. The rat with albumin serum less than $3.3 \mathrm{mg} / \mathrm{dL}$ was regarded to have nutrition deficit (Giknis and Clifford, 2008; Susanto et al., 2010). In the second phase, normal control rats (8 rats) were treated with standard pellet feed. Thirty-two malnutrition rat were randomly distributed into 4 groups; 8 rats were fed with dried rice, 8 rats were fed with $12.5 \%$ Anadara granosa -substituted dried rice (Anadara granosa flour $12.5 \%+87.5 \%$ dried rice), 8 rats were fed with 25\% Anadara granosa -substituted dried rice (Anadara granosa flour $25 \%+75 \%$ dried rice), and 8 rats were fed with 50\% Anadara granosa -substituted dried rice (Anadara granosa flour 50\% $+50 \%$ dried rice) for 8 weeks. The percentage of Anadara granosa substitution in dried rice is based on the zinc needs of children per day, which is $10 \mathrm{~g}$ (Kartono et al., 2012), then converted to rat weighing $200 \mathrm{~g}$. Food and drink for rats were given through ad libitum.

\subsection{Ethics test}

This study has obtained the ethical certificate No: 11 -KEPK from the Faculty of Public Health, Universitas Airlangga. The implementation methods were presented in front of the ethical committee and have obtained its approval.

\subsection{Procedure}

Proximate analysis of dried rice feed and feed substituted with Anadara granosa flour were carried out at the Laboratory Unit of Veterinary Faculty of Universitas Airlangga. Acclimatization, cultivation, and surgery of the test animals were carried out at the Veterinary Laboratory of Biochemical Department of Medical Faculty of Universitas Airlangga. Protein content test was carried out with the micro Kjeldahl method (AOAC, 1995). The measurement of protein content in the blood cockle flour was conducted at the Animal Feed Laboratory, Faculty of Veterinary Medicine, Universitas Airlangga. Whereas the Soxhlet method was employed to test the fat level (AOAC, 1995). In addition, the zinc level of the feed was measured using Atomic Absorbant Spectrophotometer (AAS) with the Zenit 700 tool. Further, the analysis of the zinc content of the flour was carried out at the Center for Health Laboratory, Surabaya.

As much as $3 \mathrm{~mL}$ of a blood sample from the tested rats were taken from the heart and stored within the Blood collection tube EDTA. To obtain the blood serum, the speed was set into $3000 \mathrm{rpm}$ for 15 minutes centrifuged the blood sample. The serum was then separated into Eppendorf tubes. Further, the Albumin level was tested by automatic chemical analysis Prestige 24i. Cat. No. 4-238 with Bromcresol Green (BCG) method (Doumas and Peters, 2009). The 
albumin level was stated in $\mathrm{g} / \mathrm{dL}$. The bodyweight of the tested rats was measured using a digital scale of Camry brand with the maximum capacity of $500 \mathrm{~g}$, division 0.1 $\mathrm{g}$ with the accuracy level of two numbers behind the coma.

\subsection{Statistical analysis}

The zinc and protein levels were analyzed in descriptive manner. Meanwhile, the serum albumin level of the tested rat was analyzed using One way ANOVA parametric test in the significance level of $95 \%$ and the least significant difference (LSD). Further, the body weight was analyzed using the Kruskal - Wallis test on the significance level of $95 \%$ and followed by an advance test of Mann Whitney (Steel and Torrie, 1980; McDonald, 2014).

\section{Results}

\subsection{Zinc and Protein level of Anadara granosa flour-} substituted feed

The analysis of the dried rice feed used to create malnutrition conditions and Anadara granosa substituted feed showed a different protein and zinc levels. The dried feed rice had a protein level of $8.462 \%$ and zinc $0.7913 \mathrm{ppm}$. The Anadara granosa flour had a protein level of $14.81 \%$ and zinc $0.9995 \mathrm{ppm}$. Meanwhile, dried rice feed substituted with $25 \%$ of Anadara granosa flour had a protein level of $18.74 \%$ and zinc $1.151 \mathrm{ppm}$. In addition, the 50\% substitution of Anadara granosa flour had a protein level of $26.394 \%$ and zinc $2.296 \mathrm{ppm}$ (Table 1). The level of zinc in Anadara granosa's floursubstituted feed increased along with the increase of Anadara granosa composition within the feed (Table 2). The increase of zinc level percentage on feed substituted with $12.5 \%, 25 \%$, and 50 Anadara granosa's feed-in the sequence were $26.31 \%, 45.46 \%$, and $58.35 \%$ respectively. Meanwhile, the increase of protein level of the feed substituted with $12.5 \%, 25 \%$, and $50 \%$ of Anadara granosa's flour were $75 \%, 121 \%$, and $211 \%$ in consecutive order. This showed that the substitution of Anadara granosa's flour could increase the zinc and protein level of the feed.
Table 1. Zinc and protein level of dried rice feed and Anadara granosa flour-substituted dried rice feed

\begin{tabular}{lcc}
\hline \multicolumn{1}{c}{ Types of feed } & $\begin{array}{c}\text { Zinc level } \\
\text { (ppm) }\end{array}$ & $\begin{array}{c}\text { Rough protein } \\
\text { level (\%) }\end{array}$ \\
\hline $\begin{array}{l}\text { Dried rice } \\
\text { Dried rice with } 12.5 \% \text { Anadara }\end{array}$ & 0.791 & 8.462 \\
granosa's flour substitution & 0.999 & 14.81 \\
$\begin{array}{l}\text { Dried rice with } 25 \% \text { Anadara } \\
\text { granosa's flour substitution }\end{array}$ & 1.151 & 18.74 \\
$\begin{array}{l}\text { Dried rice with 50\% Anadara } \\
\text { granosa's flour substitution }\end{array}$ & 2.296 & 26.39 \\
\hline
\end{tabular}

\subsection{Albumin level}

The results revealed that the Anadara granosa flour substitution feed significantly increased the albumin level of the malnutrition rats $(\mathrm{p}=0.000)$ (Table 3$)$. The average albumin level of malnutrition rats was $16.16 \%$ lower than a normal rat (rat fed with standard feed). In the present work, the percentage was employed to describe the decline in the albumin content due to the differences in the smaller, last number (the level of lownutrient albumin) and the initial, greater number (the normal group of albumin level). On the other hand, the use of the $\mathrm{g} / \mathrm{dL}$ unit in measuring the decline and increase in the albumin level will only hamper the process of predicting the increase or decline of the albumin content. Moreover, this percentage also applies to the increase in the albumin level; it takes into account the differences in the recent level of the albumin content of the poor-nourished mice (that had been provided with blood cockle flour) and the level of albumin in the normal group mice). The poor-nourished mice have a higher albumin level than the normal group. Another point worth considering is that the percentage provides more significant data (representing the level of albumin content).

The average albumin level of nutrition deficit rat who were treated with Anadara granosa flour substituted feed increased along with the increase of Anadara granosa's composition within the feed. The albumin level of the malnutrition rat treated with $25 \%$ and $50 \%$ of Anadara granosa's substituted feed similarly experienced an increase of $22.59 \%$. The substitution of

Table 2. Percentage of zinc and protein increase in the Anadara granosa flour-substituted feed

\begin{tabular}{|c|c|c|c|c|c|}
\hline No. & Sample & $\begin{array}{l}\text { Zinc level } \\
(\mathrm{ppm})\end{array}$ & $\begin{array}{c}\text { Zinc level increase } \\
(\%)\end{array}$ & $\begin{array}{l}\text { Rough protein level } \\
(\%)\end{array}$ & $\begin{array}{l}\text { Increase of rough } \\
\text { protein level }(\%)\end{array}$ \\
\hline 1 & Dried rice $(\mathrm{kg})$ & 0.791 & 0.00 & 8.46 & 0.00 \\
\hline 2 & $\begin{array}{l}\text { Dried rice feed substituted with } 12.5 \% \text { of } \\
\text { Anadara granosa's flour }\end{array}$ & 0.999 & 26.31 & 14.81 & 75 \\
\hline 3 & $\begin{array}{l}\text { Dried rice feed substituted with } 25 \% \text { of } \\
\text { Anadara granosa's flour }\end{array}$ & 1.151 & 45.46 & 18.74 & 121 \\
\hline 4 & $\begin{array}{l}\text { Dried rice feed substituted with } 50 \% \text { of } \\
\text { Anadara granosa's flour }\end{array}$ & 1.253 & 58.35 & 26.39 & 211 \\
\hline
\end{tabular}


Table 3. The average level of albumin (g/dL) level of malnutrition rat fed with Anadara granosa's flour-substituted feed.

\begin{tabular}{|c|c|c|c|c|c|}
\hline No. & Treatment & $\begin{array}{c}\text { Average albumin } \\
\text { level } \\
(\mathrm{g} / \mathrm{dL})\end{array}$ & $\begin{array}{c}\text { The decrease in } \\
\text { albumin level } \\
(\%)\end{array}$ & $\begin{array}{c}\text { Increase of } \\
\text { albumin level } \\
(\%)\end{array}$ & P-value \\
\hline & Rat treated with standard feed & $3.59 \pm 0.27^{\mathrm{a}}$ & 0 & 0 & \\
\hline 2 & Rat treated with dried rice feed & $3.01 \pm 0.13^{\mathrm{b}}$ & 16.16 & - & 0 \\
\hline 3 & $\begin{array}{l}\text { Rat treated with dried rice substituted with } 12.5 \% \text { Anadara } \\
\text { granosa's flour }\end{array}$ & $3.64 \pm 0.15^{\mathrm{a}}$ & - & 20.93 & \\
\hline 4 & $\begin{array}{l}\text { Rat treated with dried rice substituted with } 25 \% \text { Anadara } \\
\text { granosa's flour }\end{array}$ & $3.69 \pm 0.22^{\mathrm{a}}$ & - & 22.59 & \\
\hline 5 & $\begin{array}{l}\text { Rat treated with dried rice substituted with } 50 \% \text { Anadara } \\
\text { granosa's flour }\end{array}$ & $3.69 \pm 0.42^{\mathrm{a}}$ & - & 22.59 & \\
\hline
\end{tabular}

Notes: Average value followed by different superscript letter showed significance difference

Table 4. Average body weight (g) of malnutrition rat treated with Anadara granosa's flour- substituted feed.

\begin{tabular}{|c|c|c|c|c|c|}
\hline No. & Treatment & $\begin{array}{l}\text { Average body } \\
\text { weight } \\
(\mathrm{g}) \\
\end{array}$ & $\begin{array}{c}\text { The decrease in } \\
\text { body weight } \\
(\%)\end{array}$ & $\begin{array}{c}\text { Increase of body } \\
\text { weight } \\
(\%) \\
\end{array}$ & $\mathrm{P}$-value \\
\hline & Rat treated with standard feed & $257.43 \pm 19.28^{\mathrm{a}}$ & 0 & - & \\
\hline 2 & Rat treated with dried rice feed & $112.57 \pm 21.94^{\mathrm{b}}$ & 56.27 & - & \\
\hline 3 & $\begin{array}{l}\text { Rat treated with dried rice substituted with } 12.5 \% \text { Anadara } \\
\text { granosa's flour }\end{array}$ & $215.43 \pm 15.38^{\mathrm{c}}$ & - & 47.75 & \\
\hline 4 & $\begin{array}{l}\text { Rat treated with dried rice substituted with } 25 \% \text { Anadara } \\
\text { granosa's flour }\end{array}$ & $225.86 \pm 19.96^{\mathrm{cd}}$ & - & 50.16 & 0.002 \\
\hline 5 & $\begin{array}{l}\text { Rat treated with dried rice substituted with } 50 \% \text { Anadara } \\
\text { granosa's flour }\end{array}$ & $236.29 \pm 10.63^{d}$ & - & 50.16 & \\
\hline
\end{tabular}

Notes: Average value followed by different superscript letter showed significance difference

$12.5 \%$ of Anadara granosa's flour had improved the albumin level of malnutrition rat into the normal level.

\subsection{Bodyweight}

The result showed that the malnutrition rats fed with Anadara granosa flour substitution experienced a significant increase in body weight $(\mathrm{p}=0.002)$ (Table 4$)$. The average bodyweight of the malnutrition rats was $56.27 \%$ lower than normal rat treated with standard feed. Further, the average body weight of malnutrition rat treated with $25 \%$ and $50 \%$ of Anadara granosa flour substitution increased by $50.16 \%$.

Moreover, the bodyweight of malnutrition rat treated with feed substituted with 50\% Anadara granosa's flour was yet to achieve the maximum result, as indicated by the rats" below normal bodyweight.

\section{Discussion}

\subsection{The level of zinc and protein in the Anadara granosa} flour-substituted feed

The feed substituted with Anadara granosa flour had a higher zinc content due to the natural zinc. Similar studies by Solang et al. (2017) showed that the zinc level in cireng snack made with flour substituted with Anadara granosa flour increased. The increase of zinc in food made with Anadara granosa substitution flour indicates the Anadara granosa flour's potential as an alternative source of zinc. This is shown in several studies, where Anadara granosa are found to contain zinc level below the maximum allowed level, which is under $100 \mathrm{ppm}$ as stipulated in Malaysian Food Regulation 1985 (Ministry of Health Malaysia, 1985). In the meantime, the fresh Anadara granosa from Boalemo, Gorontalo Province, Indonesia is found to contain 13.91 ppm zinc, while the dried Anadara granosa contain 54.27 ppm zinc the boiled Anadara granosa contain 12.99 ppm zinc, and the dried, boiled Anadara granosa contain $37.86 \mathrm{ppm}$ of zinc (Nurjanah et al., 2005). On top of that, the Anadara granosa from Pohuwato regency of Gorontalo Province Indonesia was found to contain $2.70-2.82 \mathrm{ppm}$ (Solang et al., 2013). In addition, the Anadara granosa taken from Tanjung Mas and Wedung water of Semarang, Indonesia contains zinc 68.13 $94.22 \mathrm{mg} / \mathrm{kg}$ of wet weight (Taurusiana et al., 2014).

This present study also revealed that substitution of Anadara granosa's flour could increase the protein level. This signifies that the substitution of Anadara granosa's flour is one of the alternatives to improve the level of protein within the meal. This present finding supports Subaryono et al. (2003) who found that chips added with Anadara granosa had the protein level of $16.51 \%$. Solang et al. (2017) also described that supplementation of Anadara granosa increased the level of protein in Cireng snack with a percentage of 5.05\% - 54.49\%. Several other studies showed that Anadara granosa were considered as important source of protein in tropical, subtropical, and warm climate regions (Broom, 1985; Ibrahim, 1995; Nurnadia et al., 2011). The protein level of Anadara granosa was $19.8 \%$ (Nurjanah et al., 2005). 
This present study has pointed out that the higher the composition of Anadara granosa flour into a meal, the meal's zinc and protein level will also increase. Kaji and Nishi (2006) also found that main meals composed of eggs, milk, poultry, and fish have lower zinc: protein ratio compared to meals made of cockles, beef, and other red meats.

\subsection{Albumin serum level}

This present study shows that the malnutritioned rat given the dried rice were low in zinc level by $0.791 \mathrm{ppm}$, in protein level by $8.46 \%$, as well as low in albumin level by $46 \%$. It is also shown that the substitution of Anadara granosa flour increased the albumin level on the tested rat. The malnutritioned rats had an albumin level of $3.01 \mathrm{~g} / \mathrm{dL}$. The level is considered below the normal level of albumin for a rat, which was $3.3 \mathrm{~g} / \mathrm{dL}$ (Giknis and Clifford, 2008; Susanto et al., 2010). Meanwhile, the provision of feed substituted with Anadara granosa's flour could increase the albumin level of rat into the normal range, about $3.64-3.69 \mathrm{~g} / \mathrm{dL}$ (Table 3). This finding is similar to Giknis et al. (2008) who found that normal male rat had the range of albumin level between $3.4-4.8 \mathrm{~g} / \mathrm{dL}$. This present study is also similar to Kuwahata et al., (2017) who discovered that albumin concentration on rats decreased due to the decrease of protein intake and it returned to normal when the malnutrition rats were given protein intake by $20 \%$ of casein through ad libitum method. Khasanah et al. (2015), Abdullahi et al. (2018), and Gounden et al. (2018) stated that protein deficiency in food intake could lead to lack of various essential amino acid in blood serum, which needed to develop cells (synthesis) and for metabolism process as an amino acid is the precursor for albumin synthesis. The lack of amino acid in this serum would lead to a lack of albumin liver production (protein).

Provision of feed substituted with Anadara granosa flour could improve the level of albumin in malnutrition rat. This is assumed to correlate with the increase of zinc and protein level on the substituted feed (Tables 1 and 2). Choundhary (2013), described that the provision of zinc could increase protein serum. In turn, the protein contents could increase the absorption and transportation of zinc. Moreover, the presence of protein could increase the availability of amino acid as the precursor for albumin synthesis. Synthesis of albumin depends on the adequate amino acid supply (Marshall, 2012). Meanwhile, Shidhu et al. (2004) showed that the provision of zinc on protein-deficient rats could help increase the level of hepatic protein. This zinc ability is linked to its role to induce metallothionein (zinc-binding protein). Thus, it regulates the amino acid as the precursor for albumin synthesis (Tekeli, 2002).

According to the results, the Anadara granosa flour contains the amino acid, glutamate, aspartate, serine, histidine, glycine, arginine, alanine, tyrosine, methionine, valine, phenylalanine, isoleucine, leucine, and lysine. In the present study, the analysis of cysteine and proline was not performed since there was no standard for examining these amino acids. The common amino acid found in the study is glutamate. Azis (2007) reports that Anadara granosa contain cysteine. The amino acids that contribute to the metabolism of zinc are cysteine and histidine (Snedeker and Greger, 1983; Pace and Weerapana, 2014). Both of these amino acids function to transport zinc by facilitating the process of the formation of zinc-histidine and zinc-cysteine complex.

Types of amino acids that serve as a precursor of albumin synthesis are lysine, tryptophan, and isoleucine. Isoleucine and tryptophan also play a role in increasing the value of albumin synthesis (Kelman et al., 1972). Hutson et al. (1987, as cited in Harp et al., 1991) argue that the deficit of essential amino acid content, such as lysine, tryptophan, and isoleucine, can decrease the albumin release. Therefore, zinc and protein in Anadara granosa were assumed to work simultaneously to increase the availability of amino acid as a precursor for albumin synthesis; hence, increase the albumin level of malnutrition rat.

\subsection{Bodyweight}

This present study showed that the provision of dried rice feed could decrease the bodyweight of the test rat, while the Anadara granosa flour substitution feed was proven to increase the bodyweight of the tested rat. A decrease in the bodyweight of the tested rats was assumed to be caused by the low zinc and protein contents in the dried rice feed. The zinc level of dried rice was below 1 ppm (Choundhary, 2013). Meanwhile, the protein level of dried rice was $8 \%$; thus, it was considered unsuitable for the rats' protein needs at $12 \%$ (complete protein with 20 amino acids) (Smith and Mangkoewidjojo, 1987). Moreover, Shidhu et al. (2004) reported that protein deficiency decreases body weight. Meanwhile, a decrease in body weight could also blame zinc deficiency (Rossi et al., 2001; Ishikawa et al., 2008; Parveen and Dipti, 2016). The provision of Anadara granosa substituted feed could significantly improve bodyweight. This was suspected due to the increased zinc and protein level in the feed (Tables 1 and 2). Parveen and Dipti (2016) explained that zinc supplementation causes a quick bodyweight increase in the malnutrition rehabilitation phase. Budiastutik et al. (2011) also described that supplementation of zinc 
phosphate and biscuit increases body weight and height. Meanwhile, an increase of protein on the feed also regulates the bodyweight through regulating the mechanism of thermogenesis and body composition, food intake, as well as protein synthesis (WesterterpPlantenga, 2003; Greco et al., 2017). Further, Westerterp -Plantenga (2003) also explained that animal-based protein-induced higher thermogenesis than plant-based protein.

The increase of body weight in malnutrition rat fed with Anadara granosa substituted feed was assumed to correlate with the increase of albumin serum as observed in this study. The increase of albumin levels would optimize the zinc absorption of the feed. Marshall (2012) explained that albumin functions to transport zinc. As the zinc has been appropriately absorbed, the zinc content within the body was assumed to increase. This availability of zinc within the body would accelerate growth and cell differentiation (Parveen and Dipti, 2016).

\section{Conclusion}

This study has shown that the provision of feed substituted with Anadara granosa flour could improve the zinc level and protein of the feed. The increase of zinc and protein could improve the availability of zinc and protein within the body; thus, it will, in turn, improve the growth of malnutrition rats through the mechanism of albumin level improvement, which later increases growth, particularly through the increase of body weight.

\section{Conflict of interest}

The authors do not have any conflicts of interest regarding the content of the present work.

\section{Acknowledgments}

We would like to acknowledge the contribution of DP2M DIKTI for funding this research through the Competitive Grant Scheme in 2015.

\section{References}

Abdullahi, S.M., Yakubu, A.M., Bugaje, M.A. and Akuyam, S.M. (2018). Serum total protein and albumin levels among malnourished children aged 659 months in Zaria. Nigerian Journal of Paediatrics, 45(1), 15-18. https://doi.org/10.4314/njp.v45i1.4

Adriani, M. and Wirjatmadi. B. (2014). The effect of adding zinc to vitamin A on IGF-1, bone age, and linear growth in stunted children. Journal of Trace Elements in Medicine and Biology, 28(4), 431-435. https://doi.org/10.1016/j.jtemb.2014.08.007

Agustian, L., Sembiring, T. and Ariani, A. (2009). Peran Zinkum Terhadap Pertumbuhan Anak/ The role of zinc on child's growth. Sari Pediatri, 11(4), 244249. https://doi.org/10.14238/sp1 1.4.2009.244-9

AOAC [Association of Official Analytical Chemist]. (1995). Official methods of analysis of the association of official analytical chemist. 18th ed. Gaithersburg, USA: AOAC International.

Broom, M.J. (1985). The biology and culture of marine bivalve mollusks of the genus Anadara. Philippines: International Center for Living Aquatic Resources Management.

Budiastutik, I., Wirjatmadi, B. and Adriani, M. (2011). Pengaruh suplementasi zinc sulfat dan biscuit terhadap konsentrasi zinc rambut balita (program MP ASI biskuit di Kertosono Jawa Timur). Buletin Penelitian Sistem Kesehatan, 14(3), 270-281. [In Bahasa Indonesia].

Campbell, D.T. and Stanley, J.C. (1963). Experimental and quasi-experimental designs for research. Chicago: Rand Mcnally College Publishing Company.

Doumas, B.T. and Peters, T.Jr. (2009). Origin of the dyebinding method for measuring serum albumin. Clinical Chemistry, 55(3), 583-584. https:// doi.org/10.1373/clinchem.2008.112854

Ministry of Health Malaysia (1985). Malaysian Food Regulations 1985. Retrieved September 2019, from https://extranet.who.int/nutrition/gina/sites/default/ files/MYS\%201985\%20Food\%20Regulations_0.pdf

Gibson, R.S. and Ferguson, E.L. (1994). Dietary Strategy for preventing iron and zinc deficiency in Africa children presented at the Nutrition in a sustainable environment: Proceedings of the XVth International Congress of Nutrition, p. 301-303. Adelaide, Australia: Smith-Gordon.

Giknis M.L.A. and Clifford, C.B. (2008). Clinical laboratory parameters for Crl: WI (Han). Wilmington, MA: Charles River Laboratory International.

Gounden, V., Vashisht, R. and Ishwarlal, J. (2018). Hypoalbuminemia. Treasure Island, Florida, USA: Stat Pearls Publishing LLC.

Greco, E, Winquist. ALee, T.J., Collins, S. and Lebovic, Z. (2017). The Role of Source of Protein in Regulation of Food Intake, Satiety, Body Weight, and Body Composition. Journal of Nutritional Health and Food Engineering, 6(6),186-193. https:// doi.org/10.15406/jnhfe.2017.06.00223

Handley, M.A., Lyles, C.R., McCulloch, C. and Cattamanchi, A. (2018). Selecting and Improving 
Quasi-Experimental Designs in Effectiveness and Implementation Research. The Annual Review of Public Health, 39, 5-25. https://doi.org/10.1146/ annurev-publhealth-040617-014128

Harp, J.B., Goldstein, S. and Phillips, L.S. (1991). Molecular regulation of IGF-I by amino acid availability in Cultured hepatocytes. Nutrition and somatomedin. Diabetes, 40(1), 95-101. https:// doi.org/10.2337/diab.40.1.95

Chirande, L., Charwe, D., Mbwana, H., Victor, R., Kimboka S, Issaka, A.I, Baines, S.K., Dibly, M.J. and Agho, K.E. (2015). Determinants of Stunting and Severe Stunting Among Under-fives in midTanzania: Evidence from the 2010 cross-sectional household survey. BMC Pediatrics, 15(165), 1-13. https://doi.org/10.1186/s12887-015-0482-9

Choundhary, D. (2013). Influence of dietary zinc deficiency on serum zinc and protein. Indian Journal of Fundamental and Applied Life Sciences, 3(1),143148.

Ibrahim, N. (1995). The trace element content of Malaysian cockles (Anadara granosa). Food Chemistry, 54(2),133-135. https:// doi.org/10.1016/0308-8146(94)00149-Y

Ishikawa, Y., Kudo, H., Suzuki, S., Nemoto, N., Sassa, S. and Sakamoto, S. (2008). Downregulation by a low- zinc diet in gene expression of rat prostatic thymidylate synthase and thymidine kinase. Nutrition and Metabolism, 5(12), 1-5. https:// doi.org/10.1186/1743-7075-5-12

Kaji, M. and Nishi, Y. (2006). Growth and minerals: Zinc. Growth, Genetics and Hormones (GGH), 22 (1), 1-10.

Kartono, D.J., Hardinsyah, Jahari, A.B., Sulaeman, A., Astuti, M., Soekatri, M. and Riyadi H. (2012). Penyempurnaan Kecukupan Gizi Untuk Orang Indonesia. Widyakarya Nasional Pangan Dan Gizi X.20-21 November 2012. Jakarta. Retrieved September, 2019, from https://www.dropbox.com/s/ zji1wbi5ld0qwu1/akg\%202012.pdf. [In Bahasa Indonesia].

Kaur, K., Gupta, R., Saraf, S.A. and Saraf, S.K. (2014). Zinc: The Metal of Life. Comprehensive Reviews in Food Science and Food Safety, 13(4), 358- 376. https://doi.org/10.1111/1541-4337.12067

Kelman L., Saunders S.J., Wicht S., Frith L., Corrigall A., Kirsch R.E. and Terblanche J. (1972). The Effects of Amino Acids on Albumin Synthesis by the Isolated Perfused Rat Liver. Biochemical Journal, 129(4), 805-809. https://doi.org/10.1042/ bj 1290805

Kemenkes. (2018). Riset Kesehatan Daerah. Jakarta:
Badan penelitian dan pengembangankesehatan. Indonesia: Kementerian Kesehatan, Republik Indonesia. [In Bahasa Indonesia].

Khasanah, Y., Ratnayani, Ariani, D., Angwar, M. and Nuraeni, T. (2015). In Vivo Study on Albumin and Total Protein in White Rat (Rattus norvegicus) after Feeding of Enteral Formula from Tempe and Local Food. Procedia Food Science, 3, 274-279. https:// doi.org/10.1016/j.profoo.2015.01.030

Kusudaryati, D.P.D., Muis, S.F. and Widajanti, L. (2017). Pengaruh suplementasi $\mathrm{Zn}$ terhadap perubahan indeks TB/U anak stunted usia 24-36 bulan. Jurnal Gizi Indonesia, 5(2), 98-104.https:// doi.org/10.14710/jgi.5.2.98-104

Kuwahata, M., Mari, H., Yukiko, K., Yasuaki, W. and Yasuhiro, K. (2017). An oxidized/reduced state of plasma albumin reflects malnutrition due to an insufficient diet in rats. Journal of Clinical Biochemistry and Nutrition, 60(1), 70-75. https:// doi.org/10.3164/jcbn.16-33

Mardewi, K.W., Sidiartha, I.G.L. and Gunawijaya, E. (2016). Low serum zinc and short stature in children. Paediatrica Indonesiana, 56(3), 171-175. https:// doi.org/10.14238/pi56.3.2016.171-5

Marshall, W. (2012). Albumin (serum, plasma). Association for Clinical Biochemistry. Retrieved on September 2019 from website: http:// www.acb.org.uk/Nat\%20Lab\%20Med\%20Hbk/

Albumin.pdf

McDonald, J.H. (2014). Handbook of Biological Statistics. 3rd ed. Baltimore, Maryland: Sparky House Publishing.

Nurjanah, Zulhamsyah and Kustiyariyah. (2005). Kandungan mineral dan proksimatkerangdarah (Anadara granosa) yang diambil dari kabupaten Boalemo, Gorontalo. Buletin Teknologi Hasil Perikanan, 8(2), 15-24.https://doi.org/10.17844/ jphpi.v8i2.1012. [In Bahasa Indonesia].

Nurnadia, A.A., Azrina, A. and Amin, I. (2011). Proximate composition and energetic value of selected marine fish. International Food Research Journal, 18, 137-148.

Pace, N.J. and Weerapana, E. (2014). Zinc-Binding Cysteines: Diverse Functions and Structural Motifs. Biomolecules, 4(2), 419-434. https://doi.org/10.3390/ biom4020419

Parveen, M. and Dipti, B. (2016). Role of Zinc in Malnutrition. Annals of Nutritional Disorders and Therapy, 3(1), 1-4.

Rossi, L., Migliaccio, S., Corsi, A., Marzia, M., Bianco, P., Teti, A., Gambelli, L., Cianfarani, S., Paoletti, F. and Branca, F. (2001). Reduced growth and skeletal 
changes in zinc-deficient growing rats are due to Impaired growth plate activity and inanition. American Society for Nutrition Sciences, 131(4), 1142-1148. https://doi.org/10.1093/jn/131.4.1142

Shidhu, P., Garg, M.L. and Dhawan, D.K. (2004). Protective effects of zinc on oxidative stress enzymes in the liver of protein-deficient rats. Nutricion Hospitalaria, 19(6), 341-347.

Smith, J.B. and Mangkoewidjojo, S. (1987). The care, breeding, and management of experimental animals for research in the tropics. Canberra: International Development Program of Australia Universities and Collages (IDP).

Snedeker, S.M. and Greger, J.L. (1983). Metabolism of Zinc, Copper and Iron As Affected by Dietary Protein, Cysteine and Histidine. The Journal of Nutrition, 113(3), 644-652. https://doi.org/10.1093/ jn/113.3.644

Solang, M., Adriani, M. and Wirjatmadi, B. (2013). The Analysis of Blood Cockles (Anadaragranosa) Flour Suplementasi on The Concentration of Zinc, IGF-I, and Ephifiseal Plate Width of Femur Malnourished Male Rats (Rattus norvegicus). IEESE International Journal of Science and Technology, 2(4), 12-24.

Solang, M., Lamondo, D. and Kumaji, S.S. (2017). Zinc, calcium, protein, lead, mercury, and the sensorics quality of cireng snacks supplemented with blood cockle (Anadara granosa). Nusantara Bioscience, 9 (4), 385-39. https://doi.org/10.13057/nusbiosci/ n090408

Steel, R.G.D. and Torrie, J.H. (1980). Principles of Statistics for University. 2nd ed., p. 168-214. California: McGraw Hill.

Subaryono, Irianto, H.E. and Indriati, N. (2003). Fortifikasi ikan pada emping mlijo. Journal penelitian perikanan Indonesia, 9(5), 85 -94. https:// doi.org/10.15578/jppi.9.5.2003.85-94

Susanto, H., Maslikah, S.I. and Hernowati, T.E. (2010). The nutritional effects of Moringa leaf powder (Moringa oleifera) varieties of East Nusa Tenggara in albumin levels of protein-energy malnutrition of Wistar rats (In vivo study of Moringa as a candidate for supplementation therapy in cases of severe malnutrition). Prosiding Seminar Nasional MIPA: "Peran MIPA dalam Pengembangan Teknologi dan Pendidikan Berkarakter Menuju Bangsa Mandiri". Malang, Indonesia: Universitas Negeri Malang.

Taurusiana, S., Afiati, N. and Widyorini, N. (2014). Kajian Kandungan Logam Berat Besi (Fe) Dan Seng (Zn) Pada Jaringan Lunak Kerang Darah (Anadara granosa (L.) Di Perairan Tanjung Mas, Semarang Dan Perairan Wedung, Demak. Diponegoro Journal of Maquares Management of Aquatic Resources, 3 (1), 143-150. https://doi.org/10.14710/ marj.v3i1.4431 [In Bahasa Indonesia].

Tekeli, S.K. (2002). The study of effects on serum glucose, total lipid, total protein, and albumin levels of orallyzinc in rats. Trace Elements and Electrolytes, 19(1), 6-10.

Westerterp-Plantenga, M.S. (2003). The significance of protein in food intake and body weight regulation. Current Opinion in Clinical Nutrition and Metabolic Care, 6(6), 635-638. https:// doi.org/10.1097/00075197-200311000-00005

Yanagisawa, H. (2004). Zinc Deficiency and Clinical Practice. Japan Medical Association Journal, 47(8), 359-364. https://doi.org/10.1248/yakushi.128.333 